\title{
Metacognitive Strategies in the Teaching and Learning of Mathematics
}

\author{
Stephan du Toit; Gary Kotze \\ Faculty of Education, University of the Free State \\ dutoitds@ufs.ac.za; kotzeg@ufs.ac.za
}

The broad aim of this study was to investigate the use of metacognitive strategies by Grade 11 mathematics learners and their teachers. Two objectives were stated: To investigate which metacognitive strategies Grade 11 mathematics learners and mathematics teachers can employ to enhance metacognition among learners, and to investigate the extent to which Grade 11 mathematics learners and teachers use metacognitive strategies. Questionnaires were used to obtain quantitative data about the use of metacognitive strategies by learners and teachers. The findings indicate that planning strategy and evaluating the way of thinking and acting were used most by both teachers and learners. Journal-keeping and thinking aloud were used least by teachers and learners.

The purpose of teaching mathematics is to empower learners to "make sense of society" (Departement of Education (DOE), 2003, p. 9). Various stakeholders in society, for example parents, employers and tertiary institutions, exert pressure on mathematics education because mathematical competence "contributes to personal, social, scientific and economic development" (DOE, 2003, p. 9).

South African learners do not perform very well in mathematics. The aim of the Department of Education was for 50000 learners to pass mathematics with more than $50 \%$ in the 2008 National Senior Certificate (DOE, 2008, p. 12; Naude, 2007, p. 17). This aim was achieved, a total of 63038 learners scored above $50 \%$ in the 2008 NCS mathematics examination. When the total number of learners that wrote the Grade 12 mathematics is considered, a more distressing picture emerges. A total of 270097 learners wrote mathematics in 2008, therefore only $23,34 \%$ of those learners achieved more than $50 \%$ in the examination (DOE, 2008, pp. 10, 12). On international level, an even worse scenario emerges. South Africa's Grade 8 learners scored the lowest of 46 countries with a score of 264 in the 2003 Trends in Mathematics and Science Study (TIMSS), 11 points lower than in 1999 (Gonzales et al., 2004, p. 7). South Africa did not participate in the 2007 TIMSS.

How could learners' mathematical competence and performance be improved? Campione (1987, p. 136) observes that knowledge about a domain, specific procedures for operating in that domain, and general task-independent regulatory processes are three prerequisites for effective performance within some domain. De Corte adds affective components as another prerequisite (1996, pp. 34-36) by stating that expert performance in a given domain necessitates the integrated acquirement of the following four categories of aptitude, namely a structured, accessible domain-specific knowledge base; heuristic methods; affective components; and metacognition. 


\section{Defining metacognition}

Papaleontiou-Louca (2003, p. 9) states that, in the field of cognitive developmental research, metacognition has become a foremost topic since 1973. In this regard, Schoenfeld (1992, p. 9) describes "metacognition" as a term that was coined in the 1970s and only occasionally appearing in the literature of the early 1980s, but appearing with growing frequency through the decade, becoming (with problem solving) probably the most clichéd and least understood buzz words of the 1980s.

Definitions of metacognition vary. Schoenfeld (1992) asserts that

metacognition has multiple and almost disjoint meanings (for example, knowledge about one's thought processes, self-regulation during problem solving) which make it difficult to use as a concept. (pp. 2, 38, 39)

Hacker (1998, p. 11) states that there is general agreement that the definition of metacognition should at least include the following aspects: knowledge of one's knowledge; the conscious monitoring and regulating of one's knowledge; and cognitive and affective states. Metacognition is the knowledge and beliefs about cognition, in addition to the skills and strategies enabling the self-regulation of cognitive processes (De Corte, 1996, pp. 35, 36), while Papaleontiou-Louca (2003) defines metacognition as

...all processes about cognition, such as sensing something about one's own thinking, thinking about one's thinking and responding to one's own thinking by monitoring and regulating it. (p. 12)

These various definitions of metacognition have in common the emphasis on the knowledge of cognition and the monitoring and regulation of cognitive processes. The summaries of the different facets of metacognition by Hacker (1998, p. 11) and Schoenfeld (1992, pp. 38, 39) contain an additional reference to the awareness and regulating of one's affective state.

\section{Metacognition and academic performance}

Cognitive monitoring enhances learning (Paris \& Winograd; 1990, p. 15). Butler and Winne (1995, p. 245 ) assert that there is agreement among theoreticians that the most effective learners are self-regulating. Self-regulation is viewed as synonymous to metacognitive strategies (Boekaerts \& Simons, 1995, p. 85). In support Schraw (1998, p. 114) states that academic performance is improved by metacognitive regulation as learners utilise resources and existing strategies better. A study conducted by Camahalan (2006, p. 194) found that students' academic achievement is more likely to improve when they are given the chance to self-regulate and are explicitly taught metacognitive learning strategies.

\section{Metacognitive strategies}

Metacognitive strategies refer to the conscious monitoring of one's cognitive strategies to achieve specific goals, for example when learners ask themselves questions about the work and then observe how well they answer these questions (Flavell, 1981, p. 273). Boekaerts and Simons (1995, p. 91) view metacognitive strategies as the decisions learners make before, during and after the process of learning. There are various metacognitive strategies aimed at developing learners' metacognition (Costa, 1984, pp. 59-61; Blakey \& Spence, 1990, pp. 2, 3; Brown, as quoted in Boekaerts \& Simons, 1995, p. 91).

\section{Planning strategy}

At the start of a learning activity, teachers should make learners aware of strategies, rules and steps in problem solving. Time restrictions, goals and ground rules connected to the learning activity should be made explicit and internalised by the learners. Consequently, learners will keep them in mind during the learning activity and assess their performance against them. During the learning activity, teachers can encourage learners to share their progress, their cognitive procedures and their views of their conduct. As a result, learners will become more aware of their own behaviour and teachers will be able to identify problem areas in the learners' thinking (Costa, 1984, p. 59). When learning is planned by someone else, it is difficult for learners to become self-directed (Blakey \& Spence, 1990, p. 3). 


\section{Generating questions}

Blakey and Spence (1990, p. 2) state that learners should ask themselves what they know and what they do not know at the beginning of a research activity. As the research activity progresses, their initial statements about their knowledge of the research activity will be verified, clarified and expanded.

Ratner (1991, p. 32) views the questioning of given information and assumptions as a vital aspect of intelligence: Learners should pose questions for themselves before and during the reading of learning material and pause regularly to determine whether they understand the concept; if they can link it with prior knowledge; if other examples can be given; and if they can relate the main concept to other concepts. Here Muijs and Reynolds (2005, p. 63) argue that the connection of prior knowledge and new concepts should take place during the lesson and not only when a new concept is introduced. This integration of prior knowledge and new concepts enables the learner to understand the unified and interconnected nature of knowledge, while also facilitating profound understanding of subject matter (Ornstein \& Hunkins, 1998, p. 240). Integration adheres to the second of the principles for quality mathematics education (NCTMP), stated by the National Council of Teachers of Mathematics (NCTM), (NCTM, 2000, p. 2), namely a coherent curriculum in which students' mathematical concepts are linked and built on one another.

\section{Choosing consciously}

Teachers should guide learners to explore the results of their choices before and during the decision process. Therefore, learners will be able to recognise underlying relationships between their decisions, their actions and the results of their decisions. Non-judgmental feedback to learners about the consequences of their actions and choices promotes self-awareness (Costa, 1984, p. 60), and it enables the learners to learn from their mistakes, thereby supporting the fourth principle of the NCTMP of "learning... understanding, actively building new knowledge from experience..." (NCTM, 2000, p. 2).

\section{Setting and pursuing goals}

Artzt and Armour-Thomas (1998, p. 9) define goals as "expectations about the intellectual, social and emotional outcomes for students as a consequence of their classroom experiences". These goals support the first principle of the NCTMP of high expectations and support for learners. Learners who are selfregulating strive to attain a self-formulated goal while self-regulated behaviour can be adapted with changing circumstances (Diaz, Neal, \& Amaya-Williams, 1990, p. 130).

\section{Evaluating the way of thinking and acting}

Metacognition can be enhanced if teachers guide learners to evaluate the learning activity according to at least two sets of criteria (Costa, 1984, p. 60). Initially, evaluative criteria could be jointly developed with the learners to support them in assessing their own thinking. As an example, learners could be asked to assess the learning activity by stating helpful and hindering aspects and their likes and dislikes of the learning activity. Accordingly, learners keep the criteria in mind when classifying their opinions about the learning activity and they motivate the reasons for those opinions (Costa, 1984, p. 60). Guided selfevaluation can be introduced by checklists focusing on thinking processes and self-evaluation will increasingly be applied more independently (Blakey \& Spence, 1990, p. 3).

\section{Identifying the difficulty}

Costa (1984, p. 60) advises teachers to discourage the use of phrases like "I can't"; "I am too slow to..."; or "I don't know how to...". Rather, learners should identify the resources, skills and information required to attain the learning outcome. As a result, learners are assisted to distinguish between their current knowledge and the knowledge they need. They also have more conviction in seeking the right strategy for solving the problem.

\section{Paraphrasing, elaborating and reflecting learners' ideas}

Teachers should support learners to restate, translate, compare and paraphrase other learners' ideas. Consequently, learners will be better listeners to other learners' thinking and also to their own thinking (Costa, 1984, p. 61). The teacher can, for example, respond: "What you are explaining to us is..."; "I understand that you are suggesting the following...". 
Carpenter and Lehrer $(1999$, p. 22) assert that the ability to articulate one's ideas requires profound understanding of significant aspects and concepts. They view the ability to reflect as a prerequisite for articulation and that articulation requires the identification of the essence and critical elements of an activity.

\section{Clarifying learners' terminology}

Learners regularly use vague terminology when making value judgments, for example "The question is not fair" or "The question is too difficult". Teachers should elucidate these value judgments, for example "Why is the question not fair?" or "Why is the question too difficult?" (Costa, 1984, p. 61).

\section{Problem-solving activities}

In problem solving, existing knowledge is applied to an unfamiliar situation to gain new knowledge (Killen, 2000, p. 129). Problem-solving activities are ideal opportunities to enhance metacognitive strategies, as good problem solvers are generally self-aware thinkers. Learners with superior metacognitive abilities are better problem solvers. The ability to analyse their problem-solving strategies and reflect on their thinking reveals the learners' metacognitive skills (Blakey \& Spence, 1990, p. 2; Panaoura, Philippou, \& Christou, 2003, p. 3).

After the problem-solving process, teachers should encourage learners to clarify their course of action, instead of merely correcting the learner (Costa, 1984, p. 61). Goos \& Galbraith (1996, p. 231) state that non-cognitive aspects, like learners debilitating beliefs about the nature of mathematics and about themselves, could have a positive or negative effect on cognitive and metacognitive processes involved in problem solving.

When the whole class works on a problem, the teacher, instead of steering the learners to the answer, helps the learners to take full advantage of those aspects that they have produced. During this process of guiding the learners, the teacher will ask questions like: "Are you all convinced that you understand the problem?"; and "Which of the suggestions to solve the problem should we attempt first, and why?". After the class has worked on the problem for about five minutes, the teacher could ask them whether the process is going well, and if not, to reassess the strategy. If the class decides to reject that strategy, the teacher could ask whether anything helpful could be recovered from their effort. When a solution is reached, the teacher reviews the whole problem-solving process and indicates where the class went wrong initially. Teachers also lead the class in finding alternative solutions to the problem (Schoenfeld, 1987, p. 202). In this regard, Muijs and Reynolds (2005, p. 64) list reflection as one of the elements of constructivist teaching strategies. They describe reflection, a key learning moment, as the comparing of solutions between learners. They also regard reflection as the process learners engage in when they think about problem-solving strategies and their effectiveness.

Schoenfeld (1987, p. 202) considers whole class problem solving as promoting self-regulation, because the teacher's role as a moderator compels learners to focus on control decisions made by themselves, and not by the teacher. Another aspect of whole class problem solving that Schoenfeld (1987, p. 202) discusses is the opportunity it affords to pose problems that evoke beliefs about mathematics. An example is mentioned of the belief that problems can be solved relatively quickly if the subject matter is well understood. To challenge this belief, a problem is assigned that would probably take the class a few days, or even weeks, to solve.

Schoenfeld's (1987, p. 206) aim with small group problem solving is to provide learners with a range of problem-solving strategies (heuristics), and then to train them to use those strategies effectively. When learners are only taught about heuristics and then have to work on problems at home, the teacher is not present in the midst of problem solving when his/her input could have promoted the use of self-regulation skills, for example, the teacher informs the learners that they are going to be asked the following three questions whenever they work on a problem: "What exactly are you doing?"; "Why are you doing it?"; and "How does it help you?". Gradually, it becomes a matter of practice for the learners to start asking the questions themselves, thereby improving their problem-solving skills and operation on a metacognitive level. 


\section{Thinking aloud}

Teachers should promote the habit of thinking aloud when learners solve problems (Costa, 1984, p. 61). Talking about their thinking will help learners to identify their thinking skills (Blakey \& Spence, 1990, p. 2).

Muijs and Reynolds (2005, p. 64) use the term "articulation" to describe learners' expression of their own thoughts and ideas. They recommend that learners should discuss complex tasks and present their ideas to fellow learners. They furthermore suggest that group work could be very effective in promoting articulation. In this regard, Blakey and Spence (1990, p. 2) mention paired problem solving, where one learner describes his/her thinking processes while his/her partner helps him/her to clarify his thinking by listening and asking questions.

A main aspect of Vygotsky's developmental theory is that children start using language not only to communicate, but also to regulate their activities by guiding, planning and monitoring (Diaz et al., 1990, p. 135). Three consequences for self-regulation through the use of language can be identified. Firstly, children organise and restructure their perceptions in terms of their goals. Secondly, children's actions are less impulsive as they allow them to act reflectively according to their goals. Finally, language not only enables children to regulate their way of perceiving stimuli, but also to regulate their behaviour (Diaz et al. 1990, pp. 135, 136). Camp, Blom, Hebert and van Doornick, (1977, p. 160) developed a program called Think Aloud to improve self-control. Children are taught to use the following four questions when solving problems: "What is my problem?"; "How can I do it?"; “Am I using my plan?"; and "How did I do'?

\section{Journal-keeping}

Keeping a personal diary throughout a learning experience facilitates the creation and expression of thoughts and actions. Learners make notes of ambiguities, inconsistencies, mistakes, insights, and ways to correct their mistakes. Preliminary insights can be compared with changes in those insights as more information is gathered or obtained through feedback from assessment, thereby supporting the fifth principle of the NCTMP, namely, that assessment should support the learning of mathematics (Costa, 1984, p. 61; Blakey \& Spence, 1990, p. 3; NCTM, 2000, p. 2).

\section{Cooperative learning}

Cooperative learning creates the opportunity for learners to work together in small groups to enhance learning. It entails more than group work, as group work is considered as a modification of whole-class discussion. In cooperative learning, the teacher gives indirect guidance as the group works together to achieve specific learning outcomes (Killen, 2000, p. 73). Cooperative learning may promote awareness of learners' personal thinking and of others' thinking. When learners act as "tutors", the process of planning what they are going to teach, lead to independent learning and clarifying the learning material (Blakey \& Spence, 1990, p. 2).

\section{Modelling}

The NCTM lists effective teaching as a third principle of the NCTMP (NCTM, p. 2000, p. 2). Modelling occurs when teachers demonstrate the processes involved in performing a difficult task, or when teachers tell learners about their thinking and the motivation for selecting certain strategies when solving problems (Muijs \& Reynolds, 2005, p. 63). Modelling and discussion enhance learners' thinking and talking about their own thinking (Blakey \& Spence, 1990, p. 2). Schoenfeld (1987, p. 200) refers to the importance for teachers of not always presenting the finished, neat presentation of the answers on the board, but to sometimes model the problems and working through the problem step by step. Consequently, the processes yielding the correct answer (for example false starts, recoveries from false starts and interesting insights) are exposed and the chief purpose of the modelling approach is achieved, namely the centering of learners' awareness on metacognitive behaviours.

Costa (1984, p. 61) suggests that modelling could be the most effective strategy used to enhance metacognition among learners because they learn best by imitating adults. Teachers will, by thinking aloud throughout planning and problem-solving activities, demonstrate their thinking processes. Teachers, therefore, have a great responsibility because "a fair proportion of the learning problems in mathematics are actually taught to the children..." (Moodley, 1992, p. 8). Van der Walt and Maree (2007, 
p. 235) found that mathematics teachers employed question-posing strategies and think-aloud models, but that they did not sufficiently promote the implementation and practice of these strategies among learners.

Aspects that denote teachers' modelling behaviour include explaining their planning, goals and objectives to the learners and motivating their actions; acknowledging their temporary inability to answer a question, but developing pathways for finding the answer; making human mistakes, but demonstrating how to correct those mistakes; requesting comments and assessment of their actions; acting in accordance with an explicitly stated value system; the ability to explain what their strengths and weaknesses are; and expressing an understanding and valuing of learners' ideas and feelings (Costa, 1984, p. 61). Regarding the expression of understanding and the valuing of learners' ideas and feelings, Muijs and Reynolds (2005, p. 65) state that flexibility, an element of the constructivist teaching strategies, is the process whereby learners partly guide the progress of the lesson as teachers interact with learners.

Vygotsky's developmental theory proposes that the development of self-regulation originates and is enhanced by the teacher-learner social interactions (Diaz et al., 1990, p. 128). Diaz et al. (1990, p. 139) identify three characteristics of teacher-learner interactions that promote self-regulation, namely the use of reasoning and supplying reasons for commands; the gradual withdrawal of teacher control; and the combination of the previous two aspects in an atmosphere of emotional warmth and affective nurturance. De Abreu, Bishop and Pompeu (1997, p. 235) also stress the importance of affect in arguing that, although learners experience mathematics cognitively and affectively, they only have the opportunity to express the cognitive aspect.

\section{Aims of the study}

The broader aim of the study was to investigate the use of metacognitive strategies by Grade 11 mathematics teachers and their learners in the teaching and learning of mathematics in the Motheo district. The following three research questions were formulated:

- Which metacognitive strategies can Grade 11 mathematics learners and their mathematics teachers employ to enhance learners' metacognition?

- To what extent does Grade 11 mathematics teachers implement and encourage learners to use the identified metacognitive strategies?

○ To what extent do Grade 11 mathematics learners implement the identified metacognitive strategies?

\section{Research design}

\section{Form of inquiry}

Information gathered from a literature study provided an answer to the first research question, and survey research as a form of inquiry was used to collect the quantitative data required to answer the second and third research questions. A learner and a teacher questionnaire, based on the literature study, were constructed to determine the extent of the use of the metacognitive strategies in the teaching and learning of mathematics.

\section{Questionnaire}

The learner questionnaire and the teacher questionnaire comprised 37 and 47 questions respectively that were based on the use of the metacognitive strategies. The learner questionnaire determined the extent to which learners use the metacognitive strategies, except modelling, in the learning of mathematics. The teacher questionnaire investigated the extent to which teachers use the metacognitive strategies in the teaching of mathematics, and encourage the use of the metacognitive strategies in the learning of mathematics. In both questionnaires, respondents could choose any of the following options on a 4-point Likert-scale: almost never, sometimes, usually, almost always. Table 1 reflects the correspondence between questionnaire items and the metacognitive strategies. 
Table 1: Correspondence between questionnaire item number(s) and metacognitive strategies

\begin{tabular}{lll}
\hline Metacognitive strategy & Learner questionnaire item(s) & \multicolumn{1}{c}{ Teacher questionnaire item(s) } \\
\hline Planning strategy & 1,2 & 1,2 \\
Generating questions & $3,4,5$ & $3,4,5$ \\
Choosing consciously & 6,18 & 6,18 \\
Setting and pursuing goals & 7,27 & 7,27 \\
Evaluating the way of thinking & $8,9,10,11,28,29,30$ & $8,9,10,11,28,29,30$ \\
and acting & & \\
Identifying the difficulty & $12,13,14,15,16$ & $12,13,14,15,16$ \\
Paraphrasing, elaborating and & 17 & 17 \\
reflecting learners' ideas & & \\
Clarifying terminology & 15,16 & 15,16 \\
Problem-solving activities & $19,31,32,33,34,35,36,37$ & $19,41,42,43,44,45,46,47$ \\
Thinking aloud & 20 & 20 \\
Journal-keeping & $21,22,23$ & $21,22,23$ \\
Cooperative learning & $24,25,26$ & $24,25,26$, \\
Modelling & & $27,28,29,30,31,32,33,34,35,36$, \\
\end{tabular}

\section{Piloting of the questionnaire}

Four Grade 11 learners were asked to complete the pilot learner questionnaire and to note any ambiguous or vague questions. Two current Grade 11 teachers and five experienced mathematics teachers completed the learner and the teacher pilot questionnaires.

\section{Sampling}

This study focused on Grade 11 mathematics teachers and Grade 11 mathematics learners in the Motheo district. Of the five districts in the Free State, this district was the leading district regarding the pass percentage in the Senior Certificate Examination of 2006 (Free State Department of Education, 2007a, p. 4).

In the Mathematics Higher Grade (HG) Senior Certificate Examination of 2006 in this district, averages of the top 10 schools for the examination were between $69,75 \%$ and $60,13 \%$ (Free State Department of Education, 2007b). Only those schools with more than 20 learners who had written the Senior Certificate Examination in Mathematics HG (five schools) were selected for the study. Table 2 contains information about the position of the five selected schools according to the 2006 Senior Certificate Examination Mathematics HG results; the number of learners who wrote the examination; and each school's average.

Table 2: Achievement in the 2006 Senior Certificate Examination in Mathematics HG

\begin{tabular}{cccc}
\hline School & $\begin{array}{c}\text { Position in district according } \\
\text { to Mathematics HG results }\end{array}$ & $\begin{array}{c}\text { Number of learners who } \\
\text { wrote Mathematics HG }\end{array}$ & $\begin{array}{c}\text { Average percentage obtained } \\
\text { in Mathematics HG }\end{array}$ \\
\hline 1 & 2 & 25 & 68,96 \\
2 & 4 & 80 & 67,46 \\
3 & 6 & 97 & 65,46 \\
4 & 7 & 26 & 63,24 \\
5 & 8 & 77 & 62,81 \\
\hline
\end{tabular}


In total, 394 learners and their teachers from 16 classes in the five selected schools participated in the study. Thirteen teachers participated in this study; three teachers had two classes each. The respondents numbered $83 \%$ of the total number of learners (respondents and non-respondents).

\section{Limitations of the study}

Since it was not one of the aims of the study to generalise the findings to the whole population, the findings have limited value. The following aspects are considered as limitations of this study: The use of two metacognitive strategies was determined by only one item each in the teacher and learner questionnaire. Therefore, the reliability of those subscales could not be determined (see Table 1); and two items on the teacher and learner questionnaire were used to obtain information about the use of more than one metacognitive strategy (see Table 1).

\section{Reseach findings}

\section{Reliability of the questionnaire}

The Cronbach Alpha procedure is regarded as the most suitable type of reliability for survey research where items are not scored right or wrong and where each item could have different answers (McMillan \& Schumacher, 2001, p. 246, 247). The reliability scores of the learner questionnaire and teacher questionnaire were 0,88 and 0,95 respectively, indicating a high reliability on both questionnaires.

\section{The use of metacognitive strategies}

One of the research questions was to determine the extent to which each metacognitive strategy is used by teachers and learners. The precise means (X) and standard deviations (SD) of the extent to which teachers and learners use metacognitive strategies (according to the questionnaires constructed for this study) are indicated in Table 3.

Table 3: The extent to which metacognitive strategies are implemented by teachers and learners

\begin{tabular}{lcccc}
\hline & \multicolumn{2}{c}{ Teachers } & \multicolumn{2}{c}{ Learners } \\
\cline { 2 - 5 } Strategy & $\mathbf{X}$ & SD & X & SD \\
\cline { 2 - 5 } Planning strategy & 4,00 & 0,00 & 3,07 & 0,64 \\
Generating questions & 3,47 & 0,47 & 2,52 & 0,70 \\
Choosing consciously & 3,38 & 0,53 & 2,83 & 0,66 \\
Setting and pursuing goals & 3,41 & 0,56 & 2,44 & 0,69 \\
Evaluating the way of thinking and acting & 3,55 & 0,35 & 3,15 & 0,48 \\
Identifying the difficulty & 3,28 & 0,63 & 2,83 & 0,50 \\
Paraphrasing, elaborating and reflecting learners' ideas & 3,16 & 0,83 & 2,53 & 0,97 \\
Clarifying terminology & 2,91 & 1,01 & 2,61 & 0,72 \\
Problem-solving activities & 3,24 & 0,52 & 2,68 & 0,53 \\
Thinking aloud & 2,73 & 1,15 & 2,28 & 1,02 \\
Journal-keeping & 2,78 & 0,97 & 2,38 & 0,79 \\
Cooperative learning & 3,23 & 0,70 & 2,24 & 0,61 \\
Modelling & 3,22 & 0,48 & - & - \\
\hline Mean score & 3,28 & 0,43 & 2,72 & 0,38 \\
\hline
\end{tabular}


The metacognitive strategies that were implemented most by the teachers were planning strategies $(4,00)$; evaluating the way of thinking and acting $(3,55)$; and setting and pursuing goals $(3,41)$. The learners employed evaluating the way of thinking and acting $(3,15)$; planning strategies $(3,07)$; choosing consciously $(2,83)$; and identifying the difficulty $(2,83)$ most. Planning strategies and evaluating the way of thinking and acting were used to the greatest extent by both teachers and learners. This could indicate that teachers and learners were well-organised and aware of their strengths and weaknesses in mathematics.

The metacognitive strategies that were implemented least by the teachers were thinking aloud $(2,73)$; encouraging journal-keeping (2,78); and clarifying terminology (2,91). The learners employed cooperative learning $(2,24)$; thinking aloud $(2,28)$; and journal-keeping $(2,38)$ to the least extent. Thinking aloud and journal-keeping were used to the least extent by both teachers and learners. This could imply that the keeping of a reflective journal is not encouraged among learners and that learners are not keeping a written record of mistakes they tend to make and insights they gain. When considering that learners use evaluating the way of thinking and acting to the greatest extent, it seems that learners can identify their strengths, weaknesses, mistakes and successes in mathematics, but they do not keep a written record of this self-knowledge. The fact that the learners used cooperative learning, which requires the articulation of one's ideas, to the least extent, could explain why thinking aloud was used to the second least extent, as learners would be more inclined to verbally express their thoughts in a group setting than individually.

Each mean score for the extent to which a specific metacognitive strategy was implemented, was higher among the teachers than the learners. The teachers' mean score $(3,28)$ for the extent to which all the metacognitive strategies were used falls in the category "usually" to "almost always" on the 4-point Likert-scale, whereas the learners' mean score $(2,72)$ falls in the category "sometimes" to "usually". Teachers used metacognitive strategies to a greater extent than the learners, as the teachers' metacognitive mean of 3,28 as compared to the learners' metacognitive mean of 2,72 indicates.

\section{Conclusion and recommendations}

From our experience of teaching, many mathematics learners do not like mathematics because they regard it as too difficult, and they cannot see the relevance of mathematics for their everyday or future lives. Learners also regularly enquire about effective study methods in mathematics. The use of metacognitive strategies could address these concerns as teachers, by valuing learners' ideas and feelings (modelling), could assist in improving learners' attitudes towards mathematics. Learner self-regulation could also be improved by the keeping of a reflective journal. By assigning real-life problems (problem solving activities), teachers have the opportunity to show the relevance of mathematics in learners' everyday and future lives. The metacognitive strategies identified in this study could serve as a guide in ensuring effective teaching and assisting learners to study and learn mathematics effectively.

It is recommended that teachers and learners are assisted with the implementation of all the identified metacognitive strategies in the teaching and learning of mathematics, especially those that were used to the least extent by teachers and learners. Modelling and problem solving activities in a cooperative learning context are also regarded as focus areas. Further research could investigate the following aspects: The factors that play a role in the extent to which specific metacognitive strategies are used by teachers and learners; the reasons why certain metacognitive strategies are used to a greater or lesser extent by both the teachers and the learners; and the influence of the teacher-learner ratio, teaching experience, teaching qualifications, and allocated time of teaching on the use of the metacognitive strategies by the teachers. The relation between learner age, home language, and language of instruction, gender, and race on the use of the metacognitive strategies by learners could be further researched.

In a speech delivered by Naledi Pandor, the Minister of Education (Pandor, 2008), she stated that the government intends to launch an intensive teacher support programme for the improvement of teaching and learning. As the link between better academic performance and the use of the metacognitive strategies has been established by previous research, we believe that teacher support programmes must include training in the use of the metacognitive strategies to ensure better teaching and learning of mathematics. 


\section{References}

Artzt, A. F., \& Armour-Thomas, E. (1998). Mathematics teaching as problem solving: A framework for studying teacher metacognition underlying instructional practice in mathematics. Instructional Science, 26, 5-25.

Blakey, E., \& Spence, S. (1990). Developing metacognition. Eric Reproduction Services No. ED327218. Retrieved from http://www.eric.ed.gov/PDFS/ED327218.pdf

Boekaerts, M., \& Simons, P. R. (1995). Leren en instructie: Psychologie van de leerling en het leerproses. Assen: Van Gorcum.

Butler, D. L., \& Winne, P. H. (1995). Feedback and self-regulated learning: A theoretical synthesis. Review of Educational Research, 65(3), 245-281.

Camahalan, F. M. G. (2006). Effects of self regulated learning on mathematics achievement on selected Southeast Asian children. Journal of Instructional Psychology, 33(3), 194-205.

Camp, B. W., Blom, G. E., Hebert, F., \& Van Doorninck, W. J. (1977). "Think Aloud": A program for developing self-control in young aggressive boys. Journal of Abnormal Child Psychology, 5(2), 157-169.

Campione, J. C. (1987). Metacognitive components of instructional research with problem learners. In F. E Weinert. \& R. H. Kluwe (Eds.), Metacognition, motivation and understanding (pp. 117-140), Hillsdale, NJ : Lawrence Erlbaum.

Carpenter, T. P., \& Lehrer, R. (1999). Teaching and learning mathematics with understanding. In E. Fennema, \& T.A. Romberg,(Eds.), Mathematics classrooms that promote understanding (pp. 19-32). Mahwah, NJ: Lawrence Erlbaum.

Costa, A. L. (1984). Mediating the metacognitive. Educational Leadership, 11, 57-62.

de Abreu, G., Bishop, A. J., \& Pompeu, G. (1997). What children and teachers count as mathematics. In T. Nunes, \& P. Bryant (Eds.), Learning and teaching mathematics: An international perspective (pp. 233264). Hove, UK: Psychology Press Ltd.

de Corte, E. (1996). Instructional psychology: Overview. In E. de Corte \& E. Weinert (Eds.), International encyclopedia of developmental and instructional psychology (pp. 33-43). Oxford: Elsevier Science. XX PP

Department of Education. (2003). National curriculum statement Grades 10-12. General. Mathematics Pretoria: National Department of Education.

Department of Education. (2008). Abridged report: 2008 National Senior Certificate Examination Results. Pretoria: Department of Education

Diaz, R. M., Neal, C. J., \& Amaya-Williams, M. (1990). The social origins of self- regulation. In L. C. Moll (Ed.), Vygotsky and education: Instructional implications and applications of sociohistorical psychology (pp. 127-154).New York: Cambridge University Press.

Flavell, J. H. (1979). Metacognition and cognitive monitoring: A new area of cognitive-developmental inquiry. American Psychologist, 34(10), 906-911.

Flavell, J. H. (1981). Monitoring social cognitive enterprises: Something else that may develop in the area of social cognition. In J. H. Flavell \& L. Ross (Eds.), Social cognitive development: Frontiers and possible futures (pp. 272-287). New York:: Cambridge University Press.

Free State Department of Education. (2007a). Analysis of the 2006 Senior Certificate results. (LTA 2/2007 Newsletter.) Bloemfontein: Free State Department of Education.

Free State Department of Education. (2007b). Centre's position in district and province per subject: 2006. (Circular to secondary schools.) Bloemfontein: Free State Department of Education.

Gonzales, P., Guzmán, J. C., Partelow, L., Pahlke, E., Jocelyn, L., Kastberg, D., \& Williams, T. (2004). Highlights From the Trends in International Mathematics and Science Study (TIMSS) 2003. Washington, DC: National Center for Education Statistics. Retrieved from http://nces.ed.gov/pubs2005/2005005.pdf

Goos, M., \& Galbraith, P. (1996). Do it this way! Metacognitive strategies in collaborative mathematical problem solving. Educational Studies in Mathematics, 30, 229-260.

Hacker, D. J. (1998). Definitions and empirical foundations. In D. J. Hacker, J. Dunlosky, \& A. C. Graesser (Eds.), Metacognition in educational theory and practice (pp. 1-24). Mahwah, NJ: Erlbaum.

Killen, R. (2000). Teaching strategies for outcomes-based education. Landsdowne: Juta.

McMillan, J. H., \& Schumacher, S. (2001). Research in education: A conceptual introduction (5th ed.). New York: Longman.

Moodley, M. (1992). Teaching/learning mathematics: What counts? In M. Moodley, R. A. Njisane, \& N. C. Presmeg (Eds.), Mathematics Education for in-service and pre-service teachers. Pietermaritzburg: Shuter \& Shooter.

Muijs, D., \& Reynolds, D. (2005). Effective teaching: Evidence and practice (2nd ed.). London: Sage Publications. 
Naude, C. (2007, 9 October). Wiskundeplan geknou as olifante veg. Die Volksblad, p. 17.

National Council of Teachers of Mathematics. (2000). Executive summary: Principles and standards for school mathematics. Retrieved on April 24, 2009, from http://www.nctm.org/uploadedFiles/Math Standards/ 12752_exec_pssm.pdf

Ornstein, A. C., \& Hunkins, F. P. (1998). Curriculum: Foundations, principles and issues ( ${ }^{\text {rd }}$ ed.). Boston: Allyn and Bacon.

Panaoura, A., Philippou, G., \& Christou, C. (2003, March). Young pupils' metacognitive ability in mathematics. Paper presented at the Third Conference of the European Society for Research in Mathematics Education. Retrieved from http://www.dm.unipi.it/ didattica/CERME3/proceedings/Groups/ TG3/TG3_Panaoura_cerme3.pdf

Pandor, N. (2008, October 27). Address by the Minister of Education, Naledi Pandor MP, at the Maths Centre "partners in performance" lunch. Braamfontein. Retrieved on February 10, 2009, from http://www.education.gov.za/Newsroom/Speeches/Speeches2008/tabid/243/ctl/Details/mid/589/ItemID/28 29/Default.aspx

Papaleontiou-Louca, E. (2003). The concept and instruction of metacognition. Teacher Development, 7(1), 930.

Paris, S. G., \& Winograd, P. (1990). How metacognition can promote academic learning and instruction. In B. F. Jones \& L. Idol (Eds.), Dimensions of thinking and cognitive instruction (pp. 15-51). Hillsdale, NJ: Lawrence Erlbaum Associates.

Ratner, C. (1991). Vygotsky's sociohistorical psychology and its contemporary applications. New York: Plenum Press.

Schraw, G. (1998). Promoting general metacognitive awareness. International Science, 26, 113-125.

Schoenfeld, A. H. (Ed.) (1987). Cognitive science and mathematics education. London: Lawrence Erlbaum Associates.

Schoenfeld, A. H. (1992). Learning to think mathematically: Problem solving, metacognition, and sensemaking in mathematics. In D. A. Grouws (Ed.), Handbook of research on mathematics teaching and learning (pp. 334-370). New York: MacMillan.

Van der Walt, M., \& Maree, K. 2007. Do mathematics facilitators implement metacognitive strategies? South African Journal of Education, 27(2), 223-241. 